\title{
The Digital Transactions Currency for the BRICS
}

\author{
Mikhail V.Zharikov* \\ Financial University under the Government \\ of the Russian Federation \\ Moscow, Russian Federation
}

Received 03.08.2020, received in revised form 19.08.2020, accepted 10.11.2020

\begin{abstract}
The article deals with the circulation of a digital currency as a worldwide problem. The topic has theoretical and practical significance because price stability, economic growth and development and market equilibrium depend on the quality of this circulation. Currency digitization has become a particularly acute issue with the outbreak of COVID-19, which made central banks to think about contactless means of payment. The research identified the significance of the most important macroeconomic indicators which may characterise the hypothetical shared digital currency for the BRICS, namely, a shared interest rate and the quantity of digital money in circulation needed for the international use. The exchange rate of the BRICS digital currency, if it ever goes into being, is going to heavily depend on the amount of the interest rate of the hypothetical creditor of last resort. This problem is quite significant, since for the international circulation it is very important to know the proportions in which the digital currency is to be exchanged for the currencies of other countries. The theoretical significance of the article is the development of a model's basis to find the exchange rate of the digital currency. The practical significance of the paper is that it contains recommendations for foreign-exchange-market players to optimise their investment portfolios as well as for monetary authorities in the emerging economies to make some policy choices.
\end{abstract}

Keywords: BRICS, digital transactions currency, payment system, quantity of digital money, purchasing power parity of the digital currency, digitization, cryptocurrency, financial innovation.

The article was written with financial support of the Russian federal budget according to the assignment given to the Financial University.

Research area: world economy.

Citation: Zharikov, M.V. (2020). The digital transactions currency for the BRICS. J. Sib. Fed. Univ. Humanit. Soc. Sci., 13(11), 1760-1769. DOI: 10.17516/1997-1370-0681.

\footnotetext{
(C) Siberian Federal University. All rights reserved

* Corresponding author E-mail address: michaelzharikoff@gmail.com ORCID: 0000-0002-2162-5056
} 


\section{Introduction}

The modern architecture of money circulation system and money per se led to the birth of the modern Homo sapiens and the organisation of human labour at the advanced intellectual level. Economic and social scientists proved that the development of production relations and money freed humans from agriculture, allowed them to carry out a variety of activities that are not directly connected with the industrial and agricultural production. It also let them produce services such as education or health care, compose music, write poetry, create other pieces of art and carry out scientific research (Vayanos, Woolley, 2013).

This happened due to a simple reason that money is goods that satisfy all needs of an economic subject, therefore thanks to the division of labour and specialisation they may get money in exchange for poems, symphonies or lessons and in exchange for the money received they may get all the necessary goods so that they do not have to do agriculture to provide victuals for themselves. The victuals will be produced for them by other economic subjects who have the corresponding capacity, competence, and competitive advantage for that. In the end, the technological change and industrial revolution reorganised the relations between manufactured goods and money (Rousseau, Wachtel, 2011).

The modern market is dominated by the financial services whose value does not match the expenses committed to deliver them. The impressive growth of the world finance and financial technology gave birth to international transaction currencies that make it possible to account for all trade deals in real time and in the virtual environment. Money are completely torn away from the real economy and came out of control of the law of the market. COVID-19 and social distancing have created a new dimension of money relations which may in the future lead to complete elimination of physical currency from the monetary system and public use meaning total digitization of money supply.

\section{Theoretical background: The physical basis of a shared digital transactions currency of the BRICS}

The production process underwent very dramatic changes over the last hundred years. Namely, in the $19^{\text {th }}-20^{\text {th }}$ centuries to make profit, an entrepreneur used to buy labour and means of production. They used to produce finished goods that distinguished from the initially purchased one by the amount of the value added that later transformed into profit in the marketplace, after the finished goods were sold there. Now, K. Marx's formula of capital reproduction has acquired a very simplified look, namely, today money just produces grown money (Ostry, 2012).

Entrepreneurs have now freed themselves not only of the necessity to employ labour and means of production. They have also got rid of the obligation to pay wages and salary, accumulate amortisation funds, etc. This resulted in the individualisation and virtualisation of the process of capital accumulation. This also changed the way money is supplied, created and circulated. Money became one of the most important instruments of economic integration and collective (or inclusive) development of country groupings (Obstfeld, 2011).

Money has evolved all the time over the centuries. Money used to be gold, silver, copper, and paper. Now, it is electronic. There are talks about introducing digital money. In the $20^{\text {th }}$ century money circulation still used to be a nationwide problem. Today, when integration groupings have grown in number, the problem of money circulation is becoming a goal of multilateral negotiations, multilateral economic and foreign trade policies that require the harmonisation of legislation in the sphere of finance, credit and money circulation (Milesi-Ferretti, Tille, 2011).

\section{Statement of the problem}

The BRICS is a group of countries distant in terms of mostly everything: territory, culture, industry, language, society, etc. However, there exists something that has kept this multilateral forum together for almost two decades. It is clear that no real integration is possible in 
the BRICS. What is possible, though, is the creation of a digital payment system bypassing the US dollar. The BRICS may make use of the national currencies to trade in goods and services and introduce a digital transactions currency that can be circulated to make the intermediation simpler (Lane, Milesi-Ferretti, 2011).

In the contemporary world economy, there are only a very limited number of currencies which are used collectively by countries as national money. Most countries in the world prefer the US dollar to take part in the international exchange of goods and services and accumulation of foreign exchange reserves (Beetsma et al., 2016). By the same token, they maintain sovereignty and keep integrity of their own national monetary systems as well as they want to be independent in their macroeconomic policy (Gourinchas, Obstfeld, 2012). National money determines the ability of regulators to collect taxes, commit budget expenses, control interest rates and inflation, etc. At the same time, to a certain extent, currencies, such as the euro, the Swiss franc, the British pound and the Japanese yen, as well as the currencies of other advanced industrial countries, may be used for the same purposes, although they are proportionately of a smaller use (Dorrucci, McKay, 2011).

Domestically, collective or shared currencies can also be used, especially within integration agreements. The collective or shared currency becomes a common currency which replaces the national currency (Cohen, 2012). However, as some economists reckon, such a currency may still remain an extra-territory means of transactions, i.e. it is the currency which is accepted in the intraregional currency circulation only and is backed by no guaranty on part of any of the national central banks (De Haas, Horen, 2011).

At the regional level there are other examples of using collective currencies, including rare ones such as the West African franc and Central African franc, as well the common currency of Brazil and Venezuela, however, they have only a very limited use and basically exist only on paper (Kasekende, Brixova, Ndikumana, 2010).

At the same time there are examples of currencies that have become means of interna- tional settlements for a group of neighboring countries with close economic, political and cultural ties to the country of the core. They circulate parallel to the nation-bound currencies such as the South African rand in Botswana and the Indian rupee in Bhutan and Nepal (Kadayan, 2014).

The ruble of Russia can be considered an intraregional means of cross-border money transfers and a means of payment to pay for the goods and services that move across the borders of the CIS countries. However, the ruble is not widely used even in the EAEU and not accumulated as a reserve asset by the member states (Johnson, 2013).

The analysis of the collective currencies may help conclude that they can be used only as interregional means of exchange and transactions, and the only currency which has become national for a big group of countries is the euro so far. For many countries of the world the euro is a reserve currency which is widely used in foreign exchange transactions, market speculations, hedging operations and currency arbitrage, as well as a means of international liquidity, cross-border money transfers, and a currency of denominating international bonds, Eurobonds and other debt securities with high credit ratings and a high level of credibility (Boddin, Stähler, 2018).

The scientific hypothesis about the creation of a digital transactions currency for the BRICS is relevant and realistic only if it is understood as a means of exchange and cross-border means of transactions in goods and services and, perhaps, financial capital.

\section{Methods}

The research makes use of the graph method to demonstrate the dynamics of the currencies. To construct the dynamics, four currency price quotations are used for all five currencies of the BRICS at open, close, minimum and maximum prices.

The results of this paper are based on the hypothesis that if the BRICS had introduced a shared digital currency in 2020, for example, the exchange rate of that currency relative to the world's leading currencies such as the US dollar or the euro would have been described 
by the function built on average currency quotations. Since it is impossible to account for all the impact factors, to meet the goals of this paper, it is worth to display the function of the BRICS currency as dependent upon the factors which are naturally and objectively present in the national monetary systems.

\section{Discussion}

\section{The variety of forms of virtual money as a digital currency for the BRICS}

Various money types can be proposed as a physical carrier of a digital currency for the BRICS, including a cryptocurrency, quasi money, virtual money and conventional money of a central bank. There is a certain liking in the process of creating cryptocurrencies and other quasi money. What they have in common is that they are both virtual. They have no central authority responsible for their issue and circulation (Reinhart, Rogoff, 2011).

The verification of the scientific hypothesis about the BRICS shared digital currency in the research paper has revealed two most important macroeconomic indicators which characterise the potential shared money market of the BRICS, which is the common (or shared) key interest rate and the quantity of money in the BRICS digital currency required for the international use.

The key interest rate should be set up as a result of supply and demand interaction of the shared BRICS digital currency based on the liberal model of price formation. The rate which is going to be set in the end according to the principles of the free market economy can be called the shared or collective transactions rate.

The liberal model of price-formation was first constructed for the world commodity market to quote world prices for crude oil, natural gas, grain and many other commodities. The underlying research paper proposes this model as a means of finding a shared key interest rate as the price of the digital currency. The convenience of this model is that it implies no constraints for cross-border movement of goods and services, money, or financial capital flows.

Figure 1 displays foreign exchange rate dynamics of the BRICS digital currency relative to the US dollar. Figure 1 shows the exchange rate dynamics of the BRICS digital currency relative to the US dollar during 2019. It can be seen that the BRICS digital currency strengthened against the US dollar in 2019, which is explained by the fact that the currencies of the

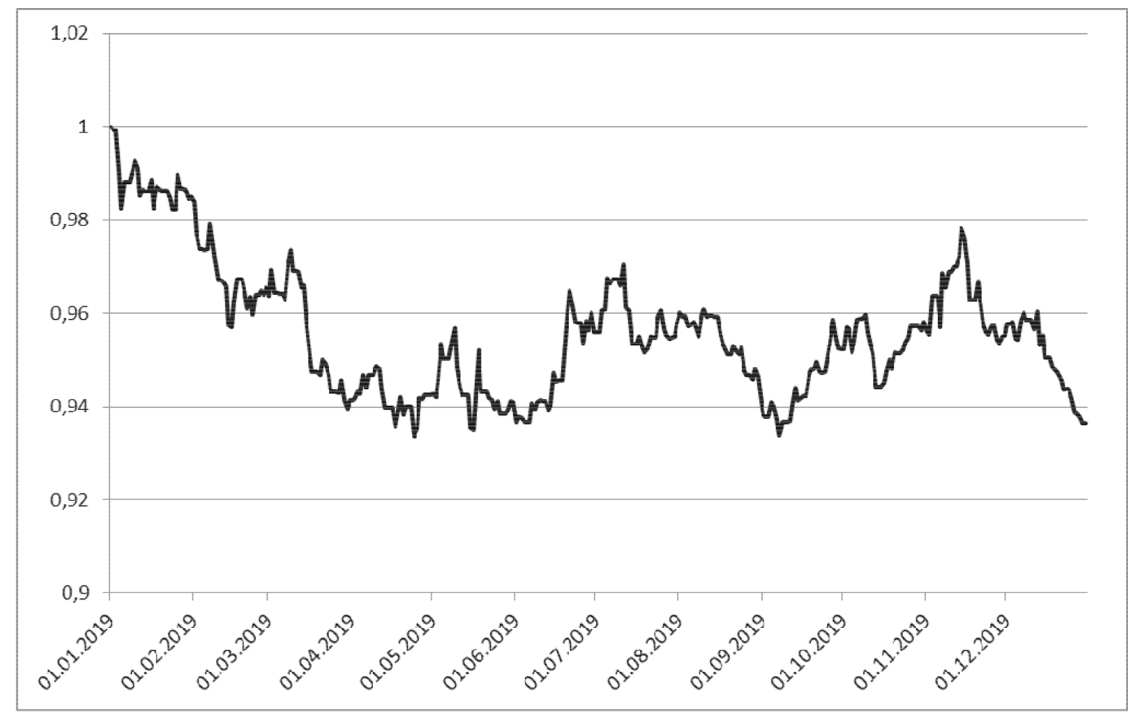

Fig. 1. Daily composite dynamics of the BRICS digital currency against the US dollar. Source: compiled by the author based on Finanz.ru. Available at: https:www.finanz.ru/valyuty (Accessed: 30.08.2020) 
BRICS steadily gained strength against the US dollar in the course of the year.

The Brazilian real, the Russian ruble and the South African rand were closest to the dynamics shown, based on the conditions on the world markets for oil, gas, grain, soya beans, gold and other minerals. The Indian rupee and the Chinese yuan did most of the strengthening against the dollar of all the BRICS currencies in 2019 (Patil, Kulkarni, 2011). The Chinese yuan, which exchange rate changes very slowly in accordance with the general gradualist policy by the government ( $\mathrm{Yu}$, 2014), started strengthening sharply against the US dollar since the second half of 2019. The pace of that strengthening outperformed the growth pattern of the yuan in the first half of 2019.

Overall, the above factors and drivers of the market conditions of the BRICS currencies can be collectively neutralised by drawing the moving average on the hypothetical dynamics of the new collective (shared) transactions currency. They also involve the corresponding changes in the direction the dynamics took in 2020 due to the spread of COVID-19.

\section{Results}

The practical significance of the curve constructed is that it helps to understand the workings of the potential BRICS' currency market. It could also help to work out a strategy for foreign-exchange-market players who might make use of it as the instrument to take financial decisions to trade in derivatives and in different segments of the world financial market.

Thus, since the emerging countries, including the BRICS, usually accumulate assets in hard currencies, then the given dynamics could be helpful in terms of making up an optimal investment portfolio in the home country, even without the common or shared money market of the BRICS, common or shared currency, common (consensual) monetary policy and common or shared central bank.

For example, according to Fig. 1, the most favourable periods of buying US dollars and, hence, storing them fell on the months of 2019 when the exchange rate of the new currency to the dollar was close to 1:1, namely January February, late June - early July and mid-November. At the macroeconomic policy level of the BRICS, their governments could make use of a similar analysis and make more contributions to the foreign exchange reserves for emergency situations, especially in Brazil, Russia and South Africa.

Apart from that, the above time periods can be signals for the central banks of the countries in question to pursue a specific monetary policy in the short run, i.e. the central bank of any BRICS country could adequately respond to an increase or decrease in the exchange rate of the national currency in anticipation of a change in the dynamics of the common (shared) transaction currency of the BRICS. At the same time, the consensual policy of the BRICS' central banks for a potential monetary cooperation should be aimed at stabilising and flattening sharp fluctuations of the new currency.

The new shared transactions currency of the BRICS can both bring benefits and costs once it is launched. There is an evidence for it from the analysis of the export and import operations of the BRICS depending on the exchange rates of the local currencies and the BRICS currency against the US dollar. The purpose of this analysis is to find economic gains which could be achieved as a result of the new currency's introduction to the foreign trade deals of the BRICS. The result is the value of the BRICS exports and imports expressed in the local currencies, the BRICS currency and the US dollar shown in Table 1.

The analysis shown in Table 1 is based on the assumption that the BRICS currency had been hypothetically used as a new collective currency to cover their export and import operations. The values of the exports and imports when the currency had first been introduced must have been both expressed in the BRICS currency and in US dollars, since the exchange rate of the new BRICS currency to the US dollar had been accepted as 1:1 in the model. According to the analysis, at the year's end of the BRICS currency's hypothetical circulation, there must have been a decrease in the foreign exchange receipts in the new currency in Brazil 
Table 1. The effectiveness of the BRICS' exports and imports in the new transactions currency, 2019

\begin{tabular}{|c|c|c|c|c|c|c|c|c|}
\hline Indicator & $\begin{array}{l}\text { The ex- } \\
\text { change rate } \\
\text { of the local } \\
\text { currency to } \\
\text { the US dollar }\end{array}$ & $\begin{array}{l}\text { The exchange } \\
\text { rate of the lo- } \\
\text { cal currency } \\
\text { to the new } \\
\text { currency of } \\
\text { the BRICS }\end{array}$ & $\begin{array}{l}\text { Exports, } \\
\text { local } \\
\text { currency, } \\
\text { billion }\end{array}$ & $\begin{array}{l}\text { Imports, } \\
\text { local } \\
\text { currency, } \\
\text { billion }\end{array}$ & $\begin{array}{l}\text { Exports, } \\
\text { the new } \\
\text { BRICS } \\
\text { currency, } \\
\text { billion }\end{array}$ & $\begin{array}{l}\text { Imports, } \\
\text { the new } \\
\text { BRICS } \\
\text { currency, } \\
\text { billion }\end{array}$ & $\begin{array}{l}\text { Exports, } \\
\text { billion } \\
\text { US } \\
\text { dollars }\end{array}$ & $\begin{array}{c}\text { Imports, } \\
\text { billion } \\
\text { US } \\
\text { dollars }\end{array}$ \\
\hline \multicolumn{9}{|c|}{ Brazil } \\
\hline year start & 3.2555 & 3.2555 & 782.1 & 756.1 & 240.2 & 232.3 & 240.2 & 232.3 \\
\hline year end & 3.3123 & 3.5370 & 824.4 & 757.8 & 233.1 & 214.3 & 248.9 & 228.8 \\
\hline \multicolumn{9}{|c|}{ Russia } \\
\hline year start & 61.6005 & 61.6005 & 22124.3 & 17685.8 & 359.2 & 287.1 & 359.2 & 287.1 \\
\hline year end & 57.6783 & 61.5909 & 23966.1 & 19041.1 & 389.1 & 309.2 & 415.5 & 330.1 \\
\hline \multicolumn{9}{|c|}{ India } \\
\hline year start & 67.9550 & 67.9550 & 27286.4 & 30449.2 & 401.5 & 448.1 & 401.5 & 448.1 \\
\hline year end & 63.8705 & 68.2032 & 29117.0 & 31330.8 & 426.9 & 459.4 & 455.9 & 490.5 \\
\hline \multicolumn{9}{|c|}{ China } \\
\hline year start & 6.9448 & 6.9448 & 14869.4 & 12468.6 & 2141.1 & 1795.4 & 2141.1 & 1795.4 \\
\hline year end & 6.9441 & 6.9441 & 14584.7 & 12943.5 & 2100.3 & 1863.9 & 2242.8 & 1990.4 \\
\hline \multicolumn{9}{|c|}{ South Africa } \\
\hline year start & 13.7366 & 13.7366 & 1315.1 & 1308.7 & 95.7 & 95.3 & 95.7 & 95.3 \\
\hline year end & 12.3775 & 13.2171 & 1385.0 & 1321.4 & 104.8 & 100.0 & 111.9 & 106.8 \\
\hline \multicolumn{9}{|c|}{ BRICS } \\
\hline year start & 1.0000 & 1.0000 & 66377.2 & 62668.5 & 3237.7 & 2858.1 & 3237.7 & 2858.1 \\
\hline year end & 0.9365 & 1.0000 & 69877.2 & 65394.7 & 3254.2 & 2946.7 & 3474.9 & 3146.6 \\
\hline
\end{tabular}

Source: composed by the author based on the data from the IMF's Principle Global Indicators. Available at: http:www. principalglobalindicators.org/regular.aspx?key=60942002 (Accessed: 30.08 .2020 ).

and China. The losses of Brazil stood at 7 billion dollars. Those of China were about 40 billion dollars. However, if both countries continued transacting in the US dollars, their foreign exchange receipts would have increased by more than 8 billion dollars and 100 billion dollars, respectively.

Russia, India and South Africa would have gained from transacting in the new BRICS currency about 65 billion dollars both in exports and imports operations. However, if India and Russia had continued to deal in the US dollars, they would have gained almost 55 billion dollars each. South Africa's gain would have amounted to about 20 billion dollars. The good news about the transactions' results shown in Table 1 is that at one point the exchange rates given date back to the early and late 2019, i.e. the period within which there could have been both positive and negative effects from foreign exchange rate fluctuations.

On the other hand, despite a general trend for the currencies of the BRICS to get stronger during 2019 on average, foreign exchange receipts could have also grown and amounted to 16 billion dollars expressed in the new currency and 240 billion real US dollars. Turning to the analysis of import transactions in the BRICS currency, it is worth mentioning that only Brazil might have gained from them, thus benefitting domestic consumers as well as domestic manufacturers which depend on the raw materials' delivery from abroad. It might have happened because the more expensive the BRICS currency would have been to the US dollar, the more capital goods and raw ma- 
terials a BRICS country might have actually bought from abroad.

Thus, the economic gain for Brazilian consumers and manufacturers would have amounted up to about 15 billion dollars expressed in the BRICS currency and only 4 billion real US dollars in equivalent terms. In the rest of the cases there would have been increases in the cost of imports both expressed in the new currency and real US dollars. If Russia had transacted in the BRICS currency, its consumers would have overspent on imports over 22 billion dollars expressed in the BRICS currency and 43 billion real US dollars. For the same purpose, Indian consumers would have overspent over 10 billion and 40 billion dollars, respectively, Chinese ones - almost 70 billion and 200 billion dollars, and South African ones - 5 billion and 10 billion dollars, respectively. Table 1 shows that consumers would have to pay more in US dollars than in the new currency of the BRICS. It means that from this point of view, taking into consideration opportunity costs involved in foreign exchange transactions, the effect from the introduction of the new currency is quite justifiable.

The major results and outcomes of this paper go down to estimating the effect of a difference between transactions in the BRICS currency and those in the US dollars to cover both the imports and exports. To this end, the theory of purchasing power parity should be used in the following interpretation. Since the foreign exchange rate of the BRICS currency against the US dollar had indeed distinguished from the exchange rate of each of the local currencies of the individual countries versus the US dollar, it must be identified how profitable and convenient it would have been to introduce the BRICS currency for all the member states when there had been changes in the scale of prices in the economy.

The theory of purchasing power parity says that a currency's depreciation (or devaluation) improves the competitiveness of a product exported from the country of that currency's origin. It means that if Russia had accepted the new common currency of the BRICS, the purchasing power parity of the initial consumer basket valued in the US dollars would have changed by a certain percentage. The consumer basket valued in the US dollars would thus become more expensive, and the goods exported from Russia could have lost their competitive advantage on the world market. Since Russia is one of the leaders in world raw materials' exports, such a change in the scale of prices might have caused a negative response from the countries importing those goods. In turn, foreign-exchange-rate risk and currency volatility might have also increased on the world foreign exchange market. Hence, there is a need to find a solution to a problem with reassessing the value of assets expressed in the local currencies, although the introduction of the new BRICS currency might have had no serious effects on the world equity market, since the overwhelming majority of foreign assets in the world are valued in the US dollars.

\section{Conclusion}

Based on the research carried out in this paper, the following deliverables can be identified:

1. There are very specific factors behind changes in the foreign exchange rates of the BRICS' local currencies. The changes in the dynamics make up the basis to construct the curve of the shared digital transactions currency for the BRICS.

2. Money went through a number of stages in its evolution. It has continually transformed in terms of the forms of value on each of the stages. It went from being physical to digital. Monetary regulation has remained mostly centralised. Decentralisation of money issue happened in time of revolutions, civil wars, anarchy, transition governments, etc. It meant decline not only in economy, but also in civilisation and culture. The destruction of the money circulation at the level of the world economy and world market may result in a number of catastrophes for the human civilisation. It means there is a need for a very cautious approach in dealing with newly emerging currencies, including collective ones and the currencies based on virtual platforms.

3 . The system of money circulation in today's world economy is not perfect. However, it continually improves and, most importantly, 
in the world today there is no more effectively working alternative but for the world monetary system based on the US dollar.

4. The international division of labour, the internationalisation of capital, production and labour exist only if there is highly developed money circulation. The modern architecture of money circulation and money itself gave birth to a human being of today and the organisation of human labour on a highly intellectual level. The development of trade and money freed humans of agriculture, let them carry out specific activities which are not directly linked with manufacturing only, work in the services sector, compose music, write fine literature, create fine arts and architecture. This happened because money is goods that satisfy all needs of a human being. Technological change and industrial revolution are impossible without real money dealings, whereas virtual money, cryptocurrencies and other quasi money do not have a real basis and cannot provide the development of social relations, civilisation, the division and specialisation of labour.

5. The international economic integration cannot go on the basis of the virtual monetary environment constituted by cryptocurrencies. It can only be done with focus on a conventional approach to money creation. If there is a possibility for the digital transactions currency of the BRICS to emerge, it is necessary to take into consideration the negative experience of the euro area, namely, the euro area was created without much attention to the correlation of foreign exchange rates dynamics. The curren- cies of the member countries of the Euro area had fluctuated independently of each other. They had different face values and were issued by countries with very diverse standards of living. The initial union of twelve countries of the EU as a monetary union was mostly motivated by the political will of the hard-core countries. Hence, the incentive to create a shared digital transactions currency for the BRICS may also come from the economically and industrially strongest country of the group which is China.

6. Since changing foreign exchange rates leads to increasing/decreasing the competitiveness of the exports from the country of issue, this means that if Russia accepts the shared digital transactions currency of the BRICS, the parity of the initial consumer baskets in dollar terms is also going to change. The basket measured in dollar terms will thus become more or less expensive, and Russian exports may lose or gain price competitive edge. Since Russia is one of the leading exporters of minerals to the world market, such change in the scale of prices will cause a certain reaction on part of the countries importing the goods. In turn, there is a possibility of increasing currency risk on the international monetary market and increasing volatility of the national currencies. Russia will also have to deal with the problem of re-estimating the assets expressed in rubles. However, since the overwhelming majority of assets in the world are expressed in the US dollars, the introduction of the shared digital transactions currency of the BRICS will hardly influence the world equity market.

\section{References}

Boddin, D., Stähler, F. (2018). The Organization of International Trade. In CESifo Working Paper, 7378, 6-10.

Beetsma, R., Giuliodori, M., De Jong, F., Widijanto, D. (2016). Price Effects of Sovereign Debt Auctions in the Euro-Zone: The Role of the Crisis. In Journal of Financial Intermediation, 25, 30-53.

Cohen, B.J. (2012). The Benefits and Costs of an International Currency: Getting the Calculus Right. In Open Economies Review, 23 (1), 16-17.

De Haas, R., Horen, N. van. (2011). Running for the Exit: International Banks and Crisis Transmission. In EBRD Working Paper, 124, 2.

Dorrucci, E., McKay, J. (2011). The International Monetary System after The Financial Crisis. In European Central Bank Occasional Paper Series, 123, 10.

Gourinchas, P.-O., Obstfeld, M. (2012). Stories of the Twentieth Century for the Twenty-First. In American Economic Journal: Macroeconomics, 4 (1), 226-265. 
Johnson, J. (2013). The Russian Federation: International Monetary Reform and Currency Internationalization. In The BRICS and Asia, Currency Internationalization and International Monetary Reform, 3, 6-15.

Kadayan, H. (2014). Indian Rupee's Role As An International Currency. In Abhinav-National Monthly Refereed Journal in Commerce \& Management, 2 (3), 35-43.

Kasekende, L., Brixova, Z., Ndikumana, L. (2010). Africa: Africa's Counter-Cyclical Policy Responses to the Crisis. In Journal of Globalization and Development, 1 (1), 10.

Lane, P.R., Milesi-Ferretti, G.M. (2011). The Cross-Country Incidence of the Global Crisis. In IMF Economic Review, 59(1), 77-110.

Milesi-Ferretti, G.M., Tille, C. (2011). The Great Retrenchment: International Capital Flows During the Global Financial Crisis. In Economic Policy, 26 (66), 285-342.

Obstfeld, M. (2011). The International Monetary System: Living With Asymmetry. In NBER Working Papers, 12596, 14.

Ostry, J. (2012). Managing Capital Flows: What Tools to Use? In Asian Development Review, 1 (2), 82-88.

Patil, S.R., Kulkarni, R.R. (2011). Internationalization of Indian Rupee - An Empirical Study. In International Journal of Research in Commerce, Economics and Management, 1, 45-49.

Reinhart, C.M., Rogoff, K.S. (2011). From Financial Crash to Debt Crisis. In American Economic Review, 101 (5), 1676-1706.

Rousseau, P.L., Wachtel, P. (2011). What Is Happening to The Impact of Financial Deepening on Economic Growth? In Economic Inquiry, 49 (1), 276-288.

Vayanos, D., Woolley, P. (2013). An Institutional Theory of Momentum and Reversal. In Review of Financial Studies, 26 (5), 1087-1145.

Yu, Y. (2014). How Far Can Renminbi Internationalization Go? In Asian Development Bank Institute's Working Paper, 461, 9-15. 


\title{
Цифровая трансакционная валюта стран БРИКС
}

\author{
М.В.Жариков \\ Финансовый университет \\ при Правительстве Российской Федерачии \\ Российская Федеращия, Москва
}

\begin{abstract}
Аннотация. Статья посвящена вопросам обращения цифровой валюты как общемировой проблемы. Тема имеет теоретическую и практическую значимость, поскольку стабильность цен, экономический рост, развитие, рыночное равновесие очень зависят от качества обращения цифровых валют в случае их широкого распространения. Цифровизация валюты и валютных отношений приобрела особую актуальность в связи с эпидемией коронавируса, что заставило центральные банки многих стран мира искать подходы к организации бесконтактного платежнорасчетного обмена. Исследование установило значимость наиболее важных макроэкономических категорий, которые характеризуют обращение гипотетической цифровой валюты стран БРИКС, а именно коллективная процентная ставка и количество цифровых денег в обращении для международного использования. Обменный курс цифровой валюты БРИКС, в случае ее появления, будет в существенной мере зависеть от размера процентной ставки гипотетического кредитора последней инстанции. Эта проблема крайне важна, поскольку в международном обмене необходимы пропорции конвертации цифровой валюты в валюты разных стран мира. Теоретическая значимость результатов статьи заключается в разработке основ модели обменного курса цифровой валюты. Практическая значимость состоит в том, что статья содержит рекомендации для участников международного валютного рынка и органов кредитно-денежного регулирования ведущих развивающихся стран в условиях функционирования цифровых валют.
\end{abstract}

Ключевые слова: страны БРИКС, цифровая трансакционная валюта, платежная система, количество цифровых денег, покупательная способность цифровой валюты, цифровизация, криптовалюта, финансовая инновация.

Статья подготовлена по результатам исследований, выполненных за счет бюджетных средств по государственному заданию Финуниверситета.

Научная специальность: 08.00.14 — мировая экономика. 